JEL Classification: E58, G01, G18, G21, N20

Keywords: banking crises, financial reforms, crisis exposures

\title{
Banking Crises and Reversals in Financial Reforms*
}

Petar STANKOV - Economics Department, Royal Holloway, University of London; Economics Department, University of National and World Economy, Bulgaria; CERGE-EI Foundation Graduate Teaching Fellow (petar.stankov@rhul.ac.uk)

\section{Abstract}

A number of countries have gone through banking crises since the early 1970s. This work links those episodes with the patterns of various financial reforms within those countries. As banking crises in a domestic economy are endogenous, exposures to banking crises in the rest of the world through the trade channel help identify the domestic banking crises. Both 2SLS and GMM estimations are used. The results demonstrate that systemic banking crises reverse financial reforms with varying lags, while non-systemic crises exert a weaker influence on financial reforms. The core methodological contribution of this work is an empirical identification strategy for occurrences of banking crises.

\section{Introduction}

Despite the rich history of both systemic and non-systemic banking crises in many countries, and the variety of policy responses to them, the financial reforms literature contains relatively little information on the specific ex-post financial reform patterns. It is still unclear which reform areas are more likely to be affected than others, how long it typically takes regulators to enact reforms in a given area, is the forcefulness of reforms related to the severity of crises, and whether a banking crisis concurrent with a recession induces faster reforms. To address those questions, economists need to look at many banking crises across a large number of countries over long periods of time. However, to date, the literature is scarce on panel data studies in this line of research.

One notable exception is the work by Abiad and Mody (2005). They study how banking crises affect the overall pattern of financial reforms across countries by using an ordered logit model. Implicitly, however, their model assumes banking crises are random events, which is arguably not the case. Banking crises are most likely determined endogenously and three channels for their incidence seem evident. First, Barth, Caprio, and Levine (2008), among others, conclude that banking system

\footnotetext{
* An earlier version of this work was publicized as CERGE-EI Working Paper no. 474 in 2012. It was supported by a grant from the CERGE-EI Foundation under a program of the Global Development Network (GDN) and by the Ministry of Finance, Japan under the Japanese Award for Outstanding Research on Development. Most of the project was done at the CERGE-EI with institutional support RVO 67985998 from the Academy of Sciences of the Czech Republic. I thank the GDN staff, and the participants at the GDN Global Development Conference in Bogota in January 2011 and the GDN Regional Conference in Prague in August 2011 for helpful comments and suggestions, especially Evangelia Vourvachaki, Seema Sangita, Randall K. Filer, Jan Kmenta, Michal Pakoš, Peter Ondko, Anna Kochanova and Vahagn Jerbashian. Jan Hanousek, Evžen Kočenda, Jan Babecký and Evan Kraft helped me finalize the working paper with valuable referee comments. Deborah Nováková who is with the Academic Skills Center at the CERGE-EI provided professional English editing support. I am also grateful to two anonymous referees at this journal for further useful suggestions. All opinions expressed are those of the author and have not been endorsed by CERGE-EI or the GDN or the Ministry of Finance, Japan. Any errors remain the sole responsibility of the author.
} 
performance, hence its fragility, may be affected by banking regulations but leave empirical work in this direction for the future. ${ }^{1}$ Demirgüç-Kunt and Detragiache (1998) also find that financial liberalization may positively influence the likelihood of a banking crisis, especially in countries with weaker banking supervision and judicial institutions. In a supporting argument, Demetriades and Law (2006) argue that financial development has larger effects on GDP per capita when the financial system is embedded within a sound institutional framework, while Rousseau and Wachtel (2011) state that the weakening of the financial development-growth link may also be a result of widespread financial liberalizations in the late 1980s and early $1990 \mathrm{~s}$ in countries that lacked the legal or regulatory infrastructure to exploit financial development successfully. Therefore, the literature is abundant with studies on how financial reforms affect the likelihood of crises but is also less informative of the link between crises and financial reforms. An implication from this duality is that any empirical study of financial reforms is prone to reverse causality issues between crises and reforms. Demetriades and Hussein (1996) are among the first to point this out. Reverse causality is only the first among many reasons to consider banking crises endogenous.

Second, it has been shown that banking crises in a given country $i$ can occur through numerous endogenous channels on both the assets and the liabilities sides of the bank balance sheet. Crises occurring on both sides have been studied by Allen and Gale $(1998,2000)$. In their earlier paper, an economic downturn in the real sector reduces the returns on bank assets. As a result, depositors put pressure on the banking sector by liquidating bank liabilities. In their latter work, banks in region $i$ liquidate claims on banks in region $j$ when there is an excess demand for liquidity in region $i$. However, the liquidity may not be readily available in region $j$, which in turn causes banks in region $j$ to contribute to the excess demand for liquidity, which drives contagion. Then, these two papers suggest that a banking crisis could not only originate in the real sector but it could also propagate across regions for reasons within both the financial and the real sector.

Third, the empirical literature adds cross-country trade and financial flows as contagion mechanisms. For example, Balakrishnan, Danninger, Elekdag, and Tytell (2011) suggest that deeper financial links are a key factor for the increased financial distress running from developed to developing economies. Trade linkages are examined as an additional factor that may drive contagion in Eichengreen, Rose, and Wyplosz (1996) and in Gorodnichenko, Mendoza, and Tesar (2012). The work by Gorodnichenko et al. (2012) is one example of how trade linkages between the former Soviet Union and Finland might have caused the Finnish output collapse in the early 1990s which was followed by a banking crisis. At the same time, the financial reforms in Finland had little to do with the origin of its trade collapse in Russia. Therefore, an output collapse or a banking crisis in a trading partner could trigger a banking crisis in a given country, without necessarily being related to the financial reforms in that country. This intuition helps identify the causality running from banking crises to financial reforms.

The identification is done by constructing banking crisis exposures for each country and period of time. The crisis exposure reveals how a banking crisis in a given trading partner $j$ affects the likelihood of a banking crisis in a given economy $i$, without

\footnotetext{
${ }^{1}$ In fact, Barth, Caprio, and Levine (2004) have already done some of this work on a cross-section of countries by using the data they collected in Barth, Caprio, and Levine (2001).
} 
directly affecting $i$ 's financial reforms. Thus, the paper identifies at least some part of the exogenous impact of banking crises on financial reforms and addresses one of the long-standing issues in the empirical literature of financial reforms: the implicit assumption of randomly occurring crises. This is the first contribution of this work.

Its second contribution is to acknowledge and incorporate the inherent dynamics of the reform process. The intuition supporting the inclusion of the reform dynamics is simple. First, if a country's financial system has not been liberalized at all, this may indicate high resistance to reform or a strong status quo bias, as in Abiad and Mody (2005). Thus, previous low levels of financial liberalization may also predict low levels in the current period. At the same time, however, high levels of financial liberalization in the past may mean that there is not much left to reform, even if the incumbent government is reform-oriented. Hence, we may observe slow reforms at high levels of financial liberalization as well. This is a path-dependent non-linear relationship which calls for inclusion of both linear and quadratic terms of lagged levels of reforms in any empirical model of reform dependence on banking crises.

However, financial reforms may occur and may also be delayed for reasons other than banking crises and reform dynamics. Past recessions and exchange rate fluctuations may well interfere with policy decisions on reforming the financial sector. Also, once countries become more open and gain from trade, they might be more likely to reduce their bias in favor of keeping the status quo and open up to financial liberalization, as in Rajan and Zingales (2003). In addition, the status quo bias against financial reforms may change at various stages of the business cycle, which would surface as a higher likelihood of opening up or re-regulating some parts of the financial system at various stages of the cycle.

There are also potential differences in how various countries respond to banking crises due to legal origin or geography, if they react at all. Morck and Yeung (2009) bring up legal origin, early land distribution, language, religion and culture as other possible fixed effects on a regulatory reform. Further, major events in a group of countries in a given period such as the economic transformation in Central and Eastern Europe in the early 1990s, the banking crises in Latin America, Asia and Eastern Europe in the late 1990s, and the more recent fiscal crisis in the Eurozone shape financial reforms as well. Those regional events which occur at a given point in time need to be taken into account in a study of any financial reform.

Based on the intuition above, the following section presents an empirical model to study financial reforms in a dynamic empirical framework with endogenously determined banking crises. The data and the results are presented next. Since some econometric concerns may arise over how the dynamic model was constructed, various robustness checks are also performed. The conclusions point to specific areas in which governments could focus financial reforms in the wake of banking crises.

\section{Methodology}

\subsection{Baseline Model}

To address the impact of a financial crisis on the ex-post financial reforms, I estimate the following model in differences: 


$$
\begin{aligned}
R_{\text {mit }}=\beta_{1} R_{\text {mit }-1} & +\beta_{2} R_{m i t-1}^{2} \\
& +\sum_{s=0}^{s *} \beta_{s} S B C_{i t-s}+\sum_{s=0}^{s *} \beta_{s} N B C_{i t-s}+Z_{i t-1}^{\prime} \beta+f_{i}+f_{r} f_{t} \\
& +\varepsilon_{m i t},
\end{aligned}
$$

where $R_{m i t}$ is the reform measure $m$ in country $i$ in period $t$ changing after a systemic banking crisis $(S B C)$ or a non-systemic banking crisis (NSBC) occurs in the same country in the current or previous two periods, and $Z_{i t-1}^{\prime}$ includes other controls. The measure $R_{m i t}$ is an index reflecting how the overall pattern of financial reforms or any of the specific financial reforms monitored by Abiad, Detragiache, and Tressel (2010), changes over time. The other controls are: a) lagged log-levels of per capita GDP and log-level of the exchange rate against the US dollar; b) the openness of the economy measured by the share of foreign trade in GDP; c) the reform gap: the difference between the highest level of the reform within the same region in year $t$ and the country's level of reform in the manner of Abiad and Mody (2005), as well as an interaction of the reform gap with GDP and the exchange rate; and d) political system variables.

Difference estimation is needed here because the data, especially on reforms, exhibits trending. Figure 1 plots the simple average of the overall reform index in each year, as well as the more detailed reform measures, against an index of crises - a simple average of the SBC and NBC dummies in each year. As we can see from the plotted data, estimations run in levels risk encountering spuriousness. Data plots, however, do not allow to adequately determine the optimal number of relevant lags for the models.

The optimal lag-length $s^{*}$ was determined by using a procedure suggested in Babecký, Havránek, Matějů, Rusnák, Šmídkova, and Vašíček (2013) and developed earlier by Love and Zicchino (2006). Similarly to Babecký et al. (2013), I use a panel vector autoregression (PVAR) technique to generate impulse-response functions (IRFs) of each financial reform to an SBC or an NBC shock. The optimal lag $s^{*}$ is then determined at the point at which an IRF of a particular reform to a shock reaches its maximum (in the case of a positive response) or minimum (in the case of a negative response). For most reforms, including the overall reform pattern, the number of optimal lags after an SBC is 2 . That is why I choose $s^{*}=2$.

The panel OLS model above has two issues which may bias the results and possibly even produce inconsistent estimates. The first issue is the endogeneity of crises which, apart from being evident in the literature, is also noticeable in Fig. 1. The second issue is the serial correlation in the presence of reform dynamics. The first issue is addressed by using an instrumental variable (IV) approach, combined with the above fixed effects panel data estimations. The second issue is addressed by using a difference GMM model in the spirit of Arellano and Bond (1991), which leads to consistent estimates even in the presence of serial correlation (Cameron and Trivedi, 2005, p.764765). A detailed presentation of those models follow.

\subsection{Instrumental Variable Estimation}

If a financial crisis is modeled as a purely random event, then the panel OLS approach to estimate the effect of a crisis would suffice for unbiased and consistent 
estimation. However, for reasons detailed above, a crisis is determined endogenously. Acknowledging the plethora of ways in which banking crises can spread across countries and over time, this work considers trade linkages to be a viable propagation mechanism of financial distress, as in Rose and Spiegel (2009) and Gorodnichenko et al. (2012). A crisis in country $i$ will be more likely if it trades with country $j$, which happens to be in a crisis. If country $j$ is in a crisis, it will likely demand less imports from country $i$. This will reduce exports from country $i$, which may induce a recession in an open economy and shrink assets in its banking sector, which in turn raises the likelihood of an asset crisis, with a certain lag. A crisis in country $i$ will be all the more likely if more than one trading partner experiences an episode of financial distress at the same time, or if its export share to a country in crisis is large, or both. Based on this premise, I construct a crisis exposure variable for each country and year. In its simplest form, the crisis exposure is an export-weighted crisis occurrence in country $i$ 's trading partners at time $t$ :

$$
\operatorname{CrExp} p_{i t}=\sum_{j} C_{j t} S_{i j t} \in[0 ; 1]
$$

where $C_{E x} E_{i t}$ is the crisis exposure of country $i$ in period $t, \mathrm{C}_{j t}$ is a dummy equal to 1 if a banking crisis occurs in country $j$ in period $t$, and $S_{i j t}$ is the share of $i$ s exports to $j$ in period $t$. Since $C_{j t}$ is either 0 or 1 , and $\sum_{j} S_{i j t}=1$, then the crisis exposure varies between 0 and 1 .

At first glance, the crisis exposure is prone to a weakness. Even if it identifies $i$ 's exposure to a shock coming from $j$, it appears to assume the crisis in $j$ to be exogenous. But the crisis in $j$ is not exogenous, as $j$ is exposed to other economies through its own trade. ${ }^{2}$ However, note that the crisis exposure is constructed in a way that captures also $j$ 's exposure. Therefore, $j$ 's crisis is also identified, as well as its own partners' crises down to the ultimate originator.

Depending on the type of crisis occurring in country $j$, two instrumental variables can simultaneously come from the crisis exposure variable - a systemic banking crisis exposure, and a non-systemic banking crisis exposure. It is also important to note that a non-systemic crisis in a large trading partner may bring a disproportionately large effect in a small open economy. Therefore, both are used as instruments for the SBC and NBC in country $i$ in the first stage of the 2SLS estimations. The results from those estimations are presented in Table A1in the Appendix.

\subsection{Correcting for Serial Correlation}

Standard panel data literature suggests that if the data contains a large time dimension, then fixed effects estimation may render consistent results even in a dynamic panel (Cameron and Trivedi, 2005, p.764). However, in some cases the linked data on banking crises and financial reforms contains just a few years of data. In fact, the maximum number of years in my sample is just below 30, which cannot be considered a large number. Therefore, the way to consistently estimate the parameters of interest in the presence of dynamics is to use a difference GMM method (Arellano and Bond,

\footnotetext{
${ }^{2}$ It is also exposed through its financial linkages but longitudinal data on bilateral financial flows is still proprietary, and the Bank for International Settlements is yet to publish it: see the CGFS (2012, p.4-5) report.
} 
1991). Apart from instrumenting with the lagged levels of the variables, the crisis exposures are kept as additional regressors in the first estimation stage. The first pass at estimating equation (1) is a one-step difference GMM with robust standard errors to both heteroskedasticity and serial correlation, in which the crisis exposures are treated as strictly exogenous. The results from the GMM estimations are presented in Table A2 in the Appendix.

As a standard procedure, the Sargan and Hansen overideintification tests are also done. As Baum, Schaffer, and Stillman (2003) note, the Sargan statistic is not valid in the presence of heteroskedasticity. Therefore, a significant difference between the Sargan test and the heteroskedasticity-robust Hansen test is expected. However, even the robust Hansen test is prone to weaknesses in the presence of many instruments. Hence, a robustness check on the GMM method is required, which reduces the number of instruments significantly. The robustness checks on the GMM method are also discussed below.

\section{Data}

The data used here to feed the models above are a combination of four data sets. The first one is a data set constructed by Caprio and Klingebiel (2003). It features the timing of 117 episodes of systemic banking crises in 93 countries since the early 1970s and of 51 borderline systemic and non-systemic crises, thereby enabling this work to qualify which crises lead to the variety of financial reforms studied here.

The Caprio and Klingebiel (2003) data is supplemented by the newer Reinhart and Rogoff (2008) work, which dates further episodes of banking crises after 2002. In addition, the Reinhart and Rogoff data set eliminates some of the dating ambiguities in the former data set, especially the ones related to the end dates of some of the crises, and thus represents an important addition to it.

The third data set was assembled by Abiad et al. (2010). It has monitored seven financial reforms annually from 1973 till 2005 across 91 countries. The reforms include imposition of credit controls, interest rate controls, entry barriers, restrictions on private ownership and banking privatization, securities and banking supervision regulations, and capital account restrictions. Each particular financial reform is coded into a discrete index $i \in[0 ; 3]-0$ if the policy is most restrictive, and 3 if the policy is most liberalized. In addition, Abiad et al. construct an overall index of financial reforms for each country and year, being equivalent to the sum of indices of each particular reform, and normalize it to 1 . To ease comparisons of estimates, I normalize the specific indices to 1 . In each set of regressions - 2SLS, and difference GMM - I take the change in each of the normalized reform indices as the dependent variable. An increase in the reform index means a more liberalized financial system, with the exception of banking supervision reform, where stricter supervisory powers are associated with an increase in the index.

The fourth data set consists of the systemic and the non-systemic crisis exposures for each country. To construct this data, I use the Caprio and Klingebiel (2003) crises data and interact each crisis episode in country $\mathrm{j}$ in year $\mathrm{t}$ with the shares of exports from country $i$ to country $j$ in year $t$. If there is no crisis in any country $j$ in a given year, then the crisis exposure in country $i$ is 0 . If there is a crisis in country $j$, then the crisis exposure is the share of exports of $i$ going to country $j$. A crisis exposure for country $i$ increases with the number of trading partners in crisis, and with the share of exports to 
a given partner in crisis. To construct a panel of bilateral export shares, I need a longitudinal bilateral trade data. Such data are available for 1970-2000 in Feenstra, Lipsey, Deng, Ma, and Mo (2005). An alternative source of bilateral trade data for 19482000 is Gleditsch (2002). Despite having a longer time coverage, the Gleditsch (2002) data has an identical matchable span to the Feenstra et al. data. Therefore, I use the Feenstra et al. data only.

The additional controls are taken from the Penn World Table 7.0. produced by Heston, Summers, and Aten (2011) and from the Database of Political Institutions prepared by Beck, Clarke, Groff, Keefer, and Walsh (2001). The GDP is the log-level of per-capita GDP; the exchange rate (XR) is the log of the exchange rate against the US dollar and its increase means an exchange rate depreciation; the openness is the share of foreign trade in GDP. The model is then estimated after differencing all the variables, including the interaction terms. The results from these estimations are presented below.

\section{Results}

Table A1 in the Appendix presents the results from estimating equation (1) in differences by 2 SLS. The table reveals several policy response patterns to financial crises. Column (1) demonstrates the effect of banking crises on the overall pattern of financial reforms. The expected significant non-linearities in the reform dynamics are indeed present. They are indicated by a negative and significant coefficient on Reform $t_{t-1}^{2}$, thereby confirming the inverted U-shape of overall reform dynamics, which was found to be significant by Abiad and Mody (2005) and Campos and Coricelli (2012). This means countries which reversed their financial liberalization in the past are less likely to reform and that those who reformed more extensively in the previous period are also less likely to undertake further reforms.

The inverted U-shape of reforms is also consistent with recent findings about a more nuanced relationship between finance and growth. Arcand, Berkes, and Panizza (2012) suggest that financial depth starts having a negative effect on output growth when credit to the private sector reaches $100 \%$ of GDP. Cecchetti, Mohanty, and Zampolli (2011) and Cecchetti and Kharroubi (2012) confirm the existence of debt thresholds for the government, the private sector and the household sector, beyond which debt can be damaging for growth, while Rousseau and Wachtel (2002) conclude that there is an inflation threshold for the finance-growth relationship beyond which finance is no longer supporting growth.

The overall response pattern is affected differently by the severity of the crisis. While non-systemic banking crises exert a significant positive influence on the overall pattern of financial reforms with a certain lag, systemic banking crises almost immediately reverse those reforms.

Similar to the overall reform patterns, credit controls are one of the areas of financial regulation in which an inverted U-shape of reform dynamics is observed. This is evident in column (2). More prominent interest rate controls are also evident in column (3) after systemic banking crises and after an exchange rate appreciation.

It may be the case that banking supervision was improved in both Europe and the US after the latest financial crisis. The results in column (5) of Table A1 in the Appendix reveal, however, that banking crises between the early 1970s and early 2000s rarely improve banking supervision. After systemic crises, governments intervene in the 
financial sector through yet another tool: ownership. The estimates in column (6) demonstrate that the state increases its ownership in the banking sector immediately after or even during the crisis itself. This is hardly surprising given the ubiquitous bailouts during a systemic crisis. Demirgüç-Kunt and Serven (2010, p.98) describe this trend as a "very common [way] of dealing with systemic banking crises" and discuss some pros and (more extensively) cons of increased government ownership in the banking sector. Unlike systemic banking crises, however, the results here suggest that non-systemic crises rarely induce governments to step in to prevent bank failure. In a more normative context, it should be also noted that if indeed the debt and inflation thresholds found in the literature (Cecchetti and Kharroubi, 2012; Cecchetti et al., 2011; Rousseau and Wachtel, 2002) are binding, government ownership should be used with more caution, especially at high levels of debt. This is because by beefing up ownership the government could break the positive loop between financial development and growth, if debt and inflation levels surpass the critical thresholds.

Governments also introduce more restrictions on capital inflows and outflows after systemic banking crises. The significant estimates in column (7) on $S B C_{t-s}$ show that systemic crises induce governments to impose stronger capital controls. Those might involve introducing special exchange rate regimes, e.g. currency boards, limiting the amount of claims that foreign banks can have on local ones, or enacting restrictions on capital outflows.

The last dimension of financial reforms that can be analyzed with the data from Abiad et al. (2010) is the securities markets policies, regulations and governing institutions. The results in column (8) demonstrate that, as with most financial reforms, securities markets experience reform reversals after systemic crises. Those reversals may stall the development of a securities market or introduce more limitations on foreign participation in the stock market.

Table A2in the Appendix demonstrate a stronger reform dynamics, as well as a stronger impact of systemic crises on financial reforms than the impact detected in Table A1 in the Appendix. Both the overall and the specific financial reforms are lagdependent, and the inverted U-shape is evident in more estimates than before. Just like the 2SLS estimates show, column (2) in Table A2 in the Appendix indicate that credit controls become more popular after systemic crises, while non-systemic crises do not exert a significant impact on both credit controls and interest rates shown in column (3).

The results in column (4) of Table A2 in the Appendix also demonstrate that systemic banking crises lead to tightening of the entry regulations in the banking industry. However, the more stringent entry policies are implemented with a sizable time lag, and the effect is significant only at the $10 \%$ level. On the one hand, this reform is rational. Limiting the number of participants in the sector, especially in combination with improved supervision on the incumbent banks, which is also evident in column (5), may impose higher costs on future risk taking, thereby reducing the probability of future crises, as implied by Thakor (2012). On the other hand, abundant theory and evidence suggests that limiting entry into the banking sector is also associated with higher loan interest rates and lower deposit rates, which hampers investment. ${ }^{3}$

\footnotetext{
${ }^{3}$ For a theoretical argument, see Besanko and Thakor (1992). Evidence is available for Turkey (Denizer, 1997), Portugal (de Pinho, 2000), Philippines (Unite and Sullivan, 2003), China (Fu and He ernan, 2009), the
} 
Column (5) in Table A2 in the Appendix demonstrate that systemic banking crises clearly improve the financial sector supervision. Still, the effect is significant only at the $10 \%$ level. The extended role of the regulators may include but is not limited to the adoption of Basel capital requirement rules, establishing a financial regulatory body which is independent of the incumbent government or chief executive, and a more comprehensive supervisory coverage, including a more pronounced role of macroprudential supervision.

Column (6) shows the increased government intervention through ownership, just like the 2SLS estimates above. The effect is stronger for systemic crises, and is insignificant for the non-systemic crises. The results in column (7) of Table A2 in the Appendix also suggest that governments impose capital flows restrictions with a significant time lag. This lag implies that capital controls may be adopted for all the wrong reasons: rather than containing a looming exchange rate crisis and limiting the risk of a subsequent banking crisis, capital controls are sometimes imposed long after the peak of the crisis. This implementation lag may limit the effectiveness of the policy and may also limit capital inflows in the aftermath of a crisis when they are needed most. Demirgüç-Kunt and Serven (2010) provide an excellent review of the drawbacks of using extensive capital account restrictions to deter a crisis.

In a nutshell, it has been shown that systemic banking crises significantly influence financial reforms, and do so more strongly than non-systemic crises. In addition, this study has found an inherent dynamic adjustment process of financial regulations, in which the degree of current reforms is affected by how much was reformed in the immediate past, with the majority of the reforms exhibiting an inverted U-shape. This adjustment is especially strong in the GMM estimates. Naturally, other factors also play a significant role in establishing the new financial regulatory realm after banking crises. Their impact can be seen in both tables.

One of the additional factors affecting financial reforms after banking crises is the business cycle. When the economy is in a recession, governments respond to it is by implementing financial liberalization reforms. This overall pattern is indicated in Column (1) of Table A2 in the Appendix, and is intuitive if governments are assumed to be rationally targeting financial development and growth. At a deeper level, three particular reform areas are affected most by a recession. They include liberalization of credit controls, improving banking supervision and reducing the ownership control over the banking sector.

First, a rational government would reduce credit controls in a recession by limiting the direct allocation of resources to favored sectors, and the monetary authorities would reduce the required reserves in the banking system to support credit activity. Second, improving banking supervision after recessions also makes sense - it could limit the riskier banking activities that likely caused the recession in the first place. Third, governments often reduce their ownership in the banking sector after a recession which may happen for two reasons. On the one hand, a recession makes losses in the banking sector more likely. If the government anticipates the losses, then it is rational to reduce its ownership in the sector for sure cash now instead of waiting for lackluster dividend prospects to materialize. On the other hand, privatizing some part of the

European Union (Corvoisier and Gropp, 2002), and for a wide cross-section of countries (Demirgüç-Kunt, Laeven, and Levine, 2004). 
banking system can spark competition in the sector, which can drive down interest rates and catalyze private activity. In addition, more competition in the banking industry is found to enhance stability (Schaeck, Cihak, and Wolfe, 2009).

Apart from the GDP dynamics, regional competition for capital inflows and policy learning also play a role in shaping financial reforms. These competition and policy learning effects, which Abiad and Mody (2005) introduced into the financial reforms literature, is evident from three variables: the reform gap, and the interaction of the gap with the GDP and with the exchange rate. Closing the gap, in theory, positions the country more favorably for attracting foreign investment. However, the results in both tables demonstrate that reducing the reform gap rarely plays a significant role in shaping overall reform patterns. The reform gap plays a role in only two of the specific financial reforms in Table A2 in the Appendix: credit controls, and securities market policies and regulations. In those two reforms, reducing the gap increases the likelihood of pursuing further financial liberalization. This learning effect is significant at the 5\% level for credit controls, and at the $1 \%$ level for the securities policies.

In the reform of credit controls and in the reform of securities markets, the gap also plays a different role at various stages of the business cycle. Countries closer to the regional reform leaders in terms of financial liberalization tend to shed their credit controls more in recessions, and pursue more favorable policies to develop the securities markets than countries lagging behind with liberalization. This is indicated by the positive and significant parameter estimates on the interaction term between the reform gap and the GDP dynamics. The positive estimates imply that governments do learn to pursue growth-enhancing policies in recessions, particularly related to developing their financial markets and to enhancing competition in the real sector by reducing direct allocation of resources to favored industries.

In addition, an exchange rate appreciation would encourage countries closer to the regional reform leaders to pursue a more extensive capital account liberalization than the backward countries. This is seen in both tables from the positive and significant sign on Gap $* X R_{t-1}$.

\section{Robustness Checks}

\subsection{Robustness of the GMM Results}

Although the GMM estimations in this work deliver new insights into the policymaking process after banking crises, they also require implicit assumptions when employing any given version of the GMM method, which are sometimes not easy to justify (Roodman, 2009). Therefore, it would be useful to know if the GMM estimation results remain robust to changing some of the main traits of the model. The baseline specification included a one-step robust difference GMM with a full set of instruments in which the crisis exposures are treated as strictly exogenous. The robustness checks are done along the following lines: 1) a two-step robust difference GMM with full set of instruments; 2) a two-step robust system GMM with full set of instruments; 3) a onestep robust difference GMM with a collapsed set of instruments; and 4) a one-step robust difference GMM with a collapsed set of instruments in which the crisis exposures are treated as possibly endogenous rather than strictly exogenous. For parsimony, the regression tables are not included in the paper but are available upon request. 
The first robustness check is driven by the expected increase in efficiency that a two-step estimation creates, at least in theory. If indeed the two-step estimation is more efficient, then the significance of the baseline results here is not artificially inflated. Alternatively, if the two-step GMM estimations are less significant than the one-step estimations, then the reason is perhaps the existence of a small sample bias of the twostep GMM discussed in Cameron and Trivedi (2005, p.177). The second robustness check is needed to see if there is an additional gain from using the system GMM rather than the original Arellano-Bond type regression. The third robustness check is needed because both the difference and the system GMM create many instruments and could deliver Sargan/Hansen P-values that are suspiciously high. Thus, limiting the number of instruments may also increase the information value of the validity tests. Finally, endogenizing the crisis exposures is intuitive. If a banking crisis in a given economy influences the risk of a crisis in another economy, then that risk would feed back into the first economy, especially if there is a large trade and financial exposure between the two. If that is indeed the case, then the crisis exposures can no longer be treated as strictly exogenous. Therefore, I endogenize them in the last robustness check on the GMM method.

The results from the first and second robustness checks yield lower significance of the parameter estimates. This refers back to the possible small sample bias of the twostep GMM. The third robustness check collapsed the number of instruments to 61 from about 1400 , by limiting the number of lags to 4 to accommodate most electoral cycles. Collapsing the number of instruments is expected to weaken the robust Hansen overidentification test. This leads to a Hansen p-value of 0.387 for the overall reform model, and to similar p-values for the other reforms. At the same time, the magnitude and the significance of the results remain almost exactly the same. Thus, the main results remain robust to the drastic reduction of the number of instruments, while the Hansen J-test acquires plausible values and increases the credibility of the results.

The final robustness check on the GMM method is to endogenize the crisis exposure variables. This corroborates the baseline results. Specifically, the reform dynamics play an identical role as before, and banking crises exert a very similar influence on the reform process, with some of the reforms affected more by the crises than the main results suggest. This supports the conclusion that the baseline results are rather conservative and that banking crises may exert an even stronger role on various financial reforms than previously thought.

\subsection{Dating of Crises}

The Caprio and Klingebiel (2003) data needs a considerable judgement on the end dates of the crises. Initially, the data by Reinhart and Rogoff (2008) seems su cient to resolve some of the dating ambiguities. However, Babecký et al. (2013) point out a considerable remaining disagreement over the duration and the end dates of many systemic and non-systemic banking crises. Therefore, I do a robustness check on that front. I replace the crisis incidences from the Caprio and Klingebiel (2003) and the Reinhart and Rogoff (2008) data with the latest data by Laeven and Valencia (2013). The robustness checks are done by performing identical estimations to the ones in Table A1 and Table A2 in the Appendix. 
The results come even stronger with the Laeven and Valencia (2013) data. In the Panel OLS estimations, 14 coefficients gained significance, while only 4 lost significance. Similarly, in the GMM estimations, 14 coefficients gained significance, while 5 lost it. The evidence in the 2SLS estimations is less strong, with 4 coefficients gaining significance, and 10 others losing it. That is why I consider the baseline results a rather conservative estimate of the effects of banking crises on financial reforms.

\subsection{Recession Exposures}

One of the possible drawbacks of the crisis exposure instruments is that they depend crucially on banking crisis occurrences in trading partners. Although crises in trading partners are arguably successful in predicting a crisis in the home country, they are hardly the only driver of those crises. An additional factor, which is perhaps not less important, is a recession in a trading partner. The hypothesis is that the likelihood of a crisis in the home country increases after a recession in a trading partner.

At the same time, a recession in a trading partner is not necessarily related to the home country's financial reform pattern. Therefore, it is related to the occurrence of a crisis in the home country but is not directly associated with its financial reforms. This logic leads me to construct an additional instrument for the incidence of crises: the recession exposure. It is constructed identically to the crisis exposure. The only difference between them being that the recession dummies in a trading partner substitute for the banking crisis dummies to arrive at the recession exposure.

When recession exposures substitute for the crisis exposures, the 2SLS estimates experience minor changes relative to the baseline results. Specifically, 5 parameters gain significance, while 6 of them lose it. The GMM estimates are virtually unchanged. Therefore, it can be concluded that the recession exposures do not change significantly the way crises affect financial reforms. The rest of the conclusions are presented below.

\section{Conclusion}

This paper uses a rich history of banking crises to identify how systemic and nonsystemic banking crises affect financial reforms. By constructing a crisis exposure for each country and year, this work adopts a more realistic propagation mechanism of crises across countries than previous literature. The crisis exposure is at the heart of identifying the causal effect of banking crises on financial reforms. Thus, this work analyzes financial reforms in a dynamic empirical framework with endogenous financial crises, which is its core methodological contribution to the literature.

The results demonstrate that systemic banking crises reverse both the overall pattern of financial reforms and some particular financial reforms, although with a varying reaction lag. Systemic banking crises prompt governments to impose more stringent interest rate controls and higher entry barriers in the financial industry, induce more state ownership in the banking sector, lead to more capital inflow and outflow controls, and slow down the creation and development of securities markets. Systemic banking crises also motivate a better banking supervision, which is perhaps a natural policy reaction to a crisis occurring in the banking sector and need not be considered a policy reversal. Non-systemic banking crises, however, exert a weaker influence on financial reforms. 
Further, recessions tend to induce financial reforms. After recessions, governments reduce their direct allocation of resources to particular industries, and reduce their ownership in the banking sector. The results remain robust to various tweaks in the GMM method and the instrumental variables, as well as to dating of the crisis episodes.

Naturally, this study has its limitations. Particularly, considering only seven broad areas of financial reforms is a low level of specificity. In addition, the paper cannot derive meaningful conclusions on the role of financial reforms for banking crises - I believe this questions has been addressed extensively in the last decade, and that has not been the main goal here. The paper also cannot say if financial reforms are moving towards a given regulatory optimum after crises. Perhaps, the optimal reforms would be different across countries and would ultimately be determined by the within-country political economy. Until better panel data sets are available to measure reforms and crisis exposures - especially longitudinal bilateral financial flows data - this is as far as this research can go. 


\section{APPENDIX}

Table A1 Crises and Financial Reforms: 2SLS Panel Estimations

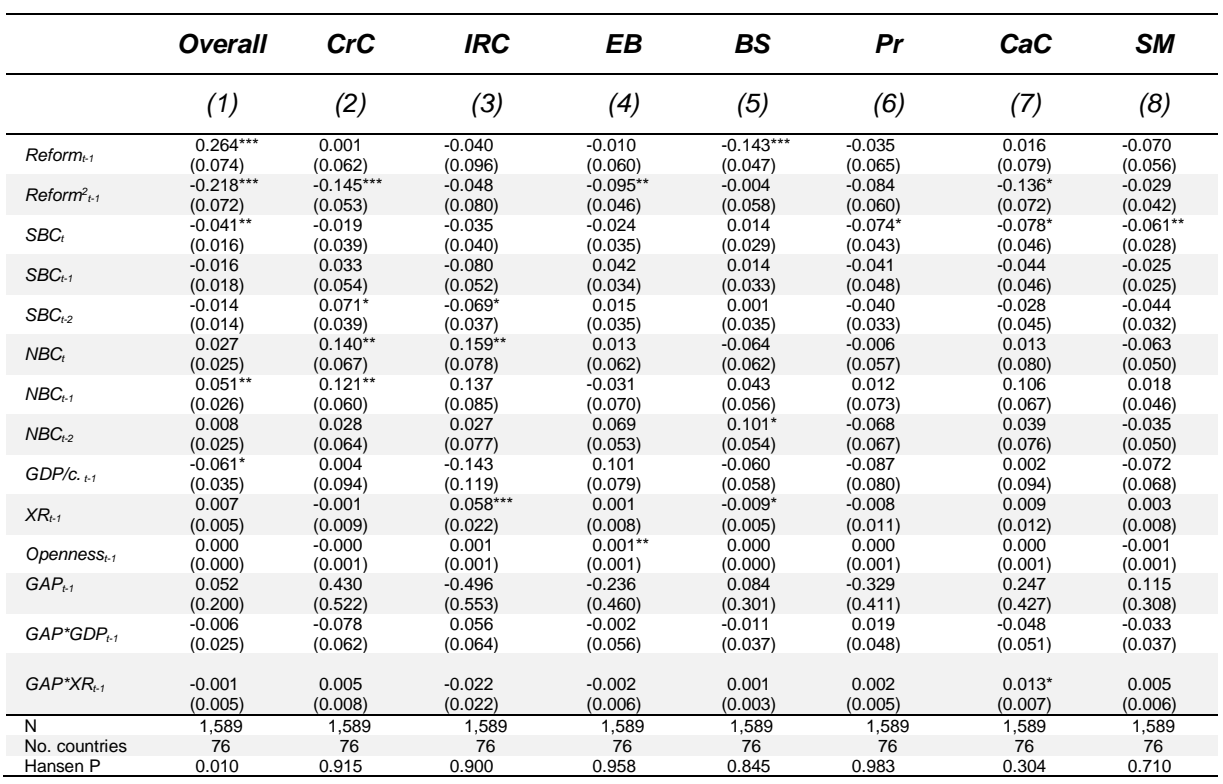

Notes: The table presents estimates of equation (1) by panel 2SLS. The time period covered is $1973-2000$ Robust standard errors are presented in parentheses. All estimations include country and region-time fixed effects. Dependent variables are: an overall index of financial reforms, as well as specific reforms, including credit controls $(\mathrm{CrC})$, interest rate controls (IRC), entry barriers and pro-competition measures in the banking system (EB), banking supervision (BS), banking privatization ( $\mathrm{Pr}$ ), capital controls (CaC), policies on the securities markets (SM). The variables Reform $t-1$ and Reform ${ }_{t-1}$ represent the lags of the respective dependent variables. SBC and NBC stand for systemic and non-systemic banking crises. The rest of the explanatory variables are detailed in the methodology section. Symbols: ${ }^{*} p<.10,{ }^{* *} p<.05$, *** $p<.01$. 
Table A2 Crises and Financial Reforms: Difference GMM

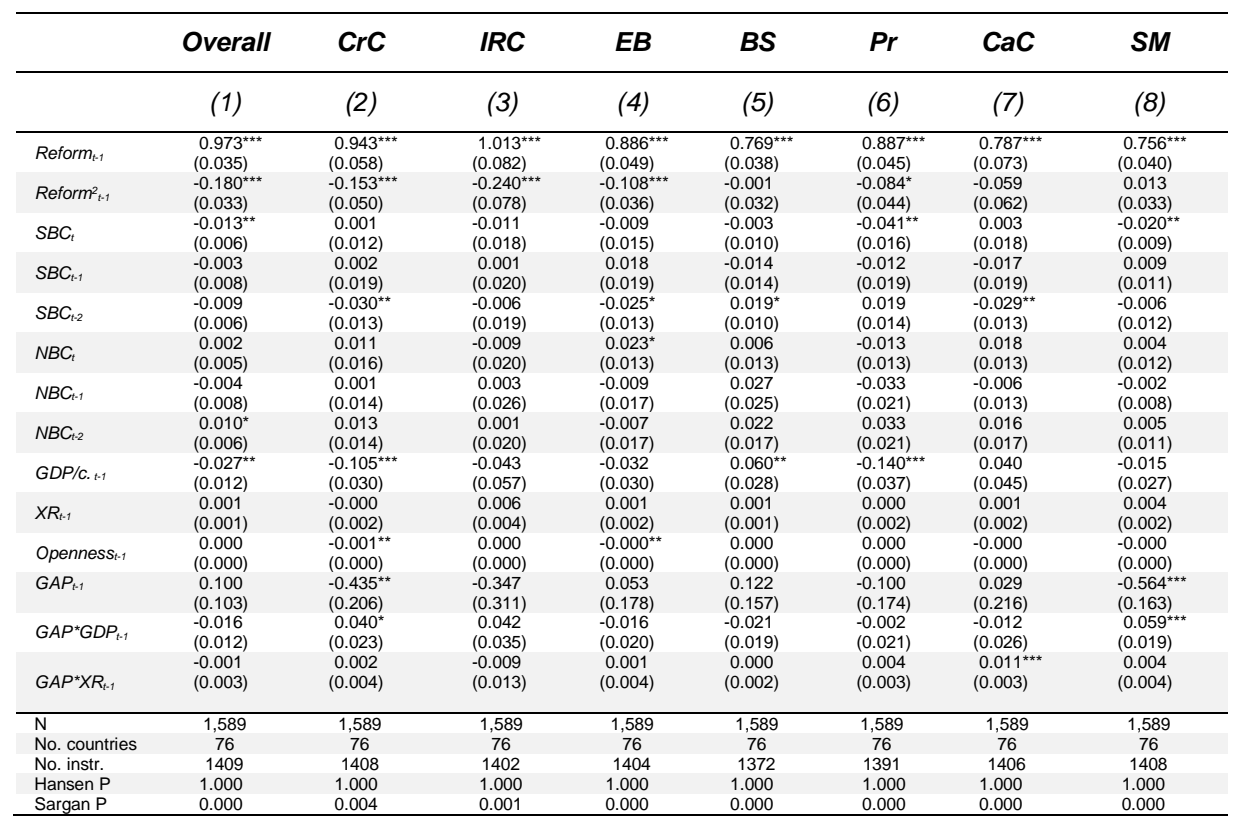

Notes: The table presents estimates from equation (1) by Arellano-Bond (1991) one-step difference GMM with full set of instruments. The time period covered is 1973-2000. Robust standard errors are presented in parentheses. All estimations include time fixed effects. Dependent variables are: an overall index of financial reforms, as well as specific reforms, including credit controls ( $\mathrm{rC}$ ), interest rate controls (IRC), entry barriers and pro-competition measures in the banking system (EB), banking supervision (BS), banking privatization $(\mathrm{Pr})$, capital controls $(\mathrm{CaC})$, policies on the securities markets $(\mathrm{SM})$. The variables

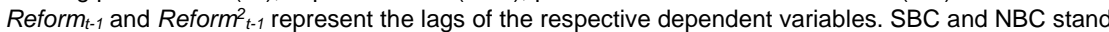
for systemic and non-systemic banking crises. The rest of the explanatory variables are detailed in the methodology section. Symbols: ${ }^{*} p<.10,{ }^{* *} p<.05,{ }^{* * *} p<.0$. 


\section{Figure A1 Banking Crises and Financial Reforms}
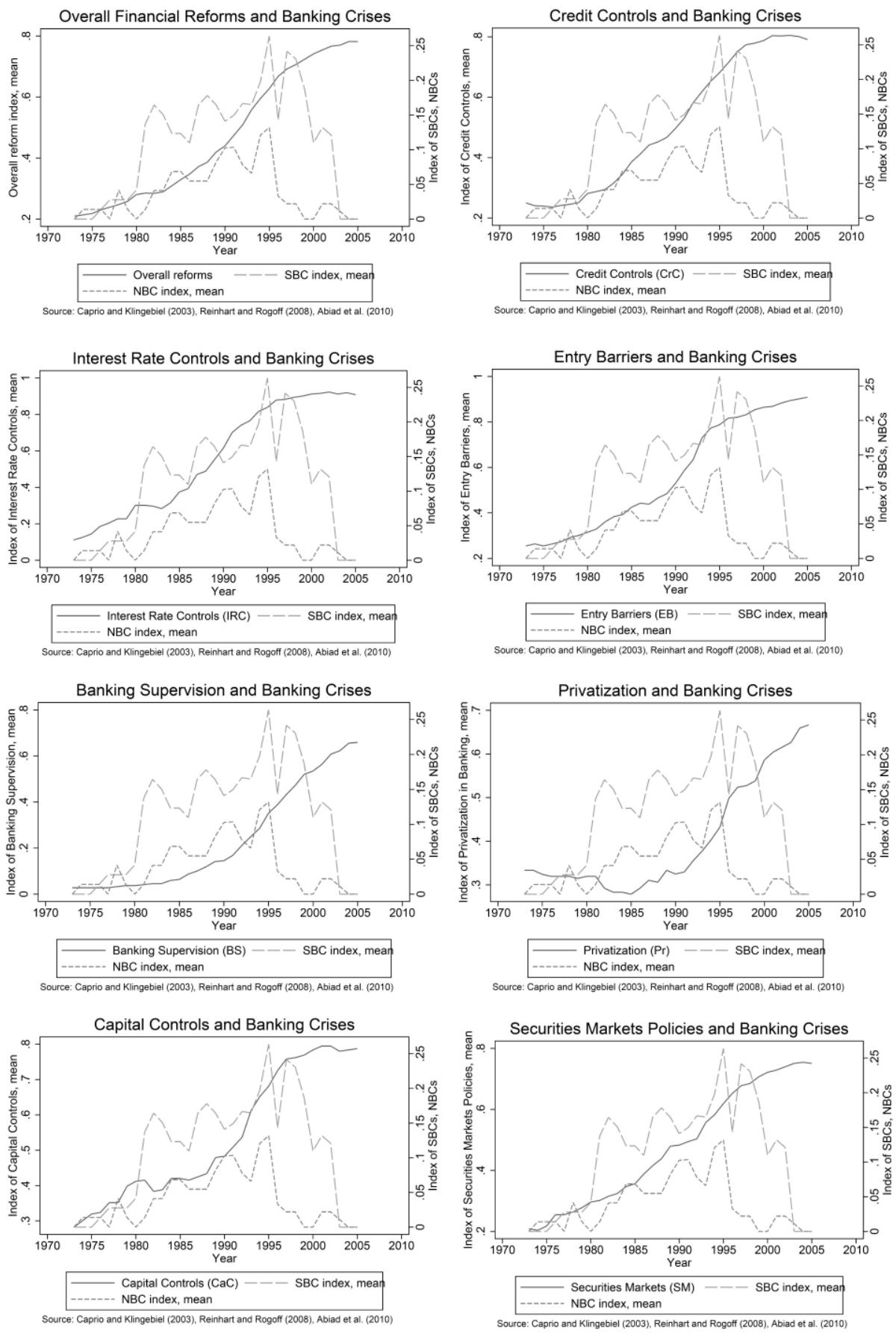

Finance a úvěr-Czech Journal of Economics and Finance, 68, 2018, no. 5 


\section{REFERENCES}

Abiad A, Detragiache E, Tressel T (2010): A New Database of Financial Reforms. IMF Staff Papers, 57(2): 281-302.

Abiad A, Mody A (2005): Financial Reform: What Shakes It? What Shapes It? American Economic Review, 95(1):66-88.

Allen F, Gale D (1998): Optimal Financial Crises. The Journal of Finance, 53(4):1245-1284.

Allen F, Gale D (2000): Financial Contagion. Journal of Political Economy, 108(1):1-33.

Arcand J-L, Berkes, E, Panizza U (2012): Too Much Finance? IMF Working Papers, 12/161, International Monetary Fund.

Arellano M, Bond S (1991): Some Tests of Specification for Panel Data: Monte Carlo Evidence and an Application to Employment Equations. The Review of Economic Studies, 58(2):277-297.

Babecký J, Havránek T, Matějů J, Rusnák M, Šmídkova K, Vašíček B (2013): Leading Indicators of Crisis Incidence: Evidence from Developed Countries. Journal of International Money and Finance, 35:1-19.

Balakrishnan R, Danninger S, Elekdag S, Tytell I (2011): The Transmission of Financial Stress from Advanced to Emerging Economies. Emerging Markets Finance and Trade, 47(Supplement 2):40-68.

Barth JR, Caprio G, Levine R (2001): The Regulation and Supervision of Banks Around the World - A New Database. Policy Research Working Paper Series, 2588, The World Bank.

Barth JR, Caprio G, Levine R (2004): Bank Regulation and Supervision: What Works Best? Journal of Financial Intermediation, 13(2):205-248.

Barth JR, Caprio G, Levine R (2008): Bank Regulations are Changing: For Better or Worse? Policy Research Working Paper Series, 4646, The World Bank.

Baum CF, Schaffer ME, Stillman S (2003): Instrumental Variables and GMM: Estimation and Testing. Stata Journal, 3(1):1-31.

Beck T, Clarke G, Groff A, Keefer P, Walsh P (2001): New Tools in Comparative Political Economy: The Database of Political Institutions. The World Bank Economic Review, 15(1):165-176.

Besanko D, Thakor AV (1992): Banking Deregulation: Allocational Consequences of Relaxing Entry Barriers. Journal of Banking \& Finance, 16(5):909-932.

Cameron AC, Trivedi PK (2005): Microeconometrics: Methods And Applications. Cambridge Books. Cambridge University Press.

Campos NF. Coricelli F (2012): Financial Liberalization and Reversals: Political and Economic Determinants. Economic Policy, 27(71):483-513.

Caprio G, Klingebiel D (2003): Episodes of Systemic and Borderline Financial Crises. Dataset 1. Mimeo. Washington, D.C.: World Bank.

Cecchetti S, Kharroubi E (2012): Reassessing the Impact of Finance on Growth. BIS Working Papers, 381, Bank for International Settlements.

Cecchetti S, Mohanty M, Zampolli F (2011, September): The Real Effects of Debt. BIS Working Papers, 352, Bank for International Settlements.

CGFS (2012): Improving the BIS international banking statistics. CGFS Papers, 47, BIS.

Corvoisier S, Gropp R (2002): Bank Concentration and Retail Interest Rates. Journal of Banking \& Finance, 26(11):2155-2189.

de Pinho PS (2000): The Impact of Deregulation on Price and Non-Price Competition in the Portuguese Deposits Market. Journal of Banking \& Finance, 24(9):1515-1533.

Demetriades P, Hussein K (1996): Does Financial Development Cause Economic Growth? Time-Series Evidence from 16 Countries. Journal of Development Economics, 51(2):387-411.

Demetriades P, Law SH (2006): Finance, Institutions and Economic Development. International Journal of Finance \& Economics, 11(3):245-260. 
Demirgüç-Kunt, A, Detragiache D (1998): Financial Liberalization and Financial Fragility. Policy Research Working Paper Series, 1917, The World Bank.

Demirgüç-Kunt A, Laeven L, Levine R (2004): Regulations, Market Structure, Institutions, and the Cost of Financial Intermediation. Journal of Money, Credit and Banking, 36(3):593-622.

Demirgüç-Kunt A, Serven L (2010): Are All the Sacred Cows Dead? Implications of the Financial Crisis for Macro and Financial Policies. The World Bank Research Observer, 25(1):91-124.

Denizer C (1997): The Effects of Financial Liberalization and New Bank Entry on Market Structure and Competition in Turkey. Policy Research Working Paper Series, 1839, The World Bank.

Eichengreen B, Rose AK, Wyplosz C (1996): Contagious Currency Crises. Working Paper 5681, National Bureau of Economic Research.

Feenstra RC, Lipsey RE, Deng H, Ma AC, Mo H (2005): World Trade Flows: 1962-2000. Working Paper 11040, National Bureau of Economic Research.

Fu XM, Heffernan S (2009): The Effects of Reform on China's Bank Structure and Performance. Journal of Banking \& Finance, 33(1):39-52.

Gleditsch KS (2002): Expanded Trade and GDP Data. Journal of Conflict Resolution, 46(5):712-724.

Gorodnichenko Y, Mendoza EG, Tesar LL (2012): The Finnish Great Depression: From Russia with Love. American Economic Review, 102(4):1619-1644.

Heston A, Summers R, Aten B (2011): Penn World Table Version 7.0. Center for International Comparisons of Production, Income and Prices at the University of Pennsylvania.

Laeven L, Valencia F (2013): Systemic Banking Crises Database. IMF Economic Review, 61(2):225270.

Love I, Zicchino L (2006): Financial Development and Dynamic Investment Behavior: Evidence from Panel VAR. The Quarterly Review of Economics and Finance, 46(2):190-210.

Morck R, Yeung B (2009): Never Waste a Good Crisis: A Historical Perspective on Comparative Corporate Governance. Annual Review of Financial Economics, 1:145-179.

Rajan RG, Zingales L (2003): The Great Reversals: The Politics of Financial Development in the Twentieth Century. Journal of Financial Economics, 69(1):5-50.

Reinhart CM, Rogoff KS (2008): Banking Crises: An Equal Opportunity Menace. Working Paper 14587, National Bureau of Economic Research.

Roodman D (2009): How to Do Xtabond2: An introduction to Difference and System Gmm in Stata. Stata Journal, 9(1):86-136.

Rose AK, Spiegel MM (2009): Cross-Country Causes and Consequences of the 2008 Crisis: International Linkages and American Exposure. Working Paper 15358, National Bureau of Economic Research.

Rousseau PL, Wachtel P (2002): Inflation Thresholds and the Finance-Growth Nexus. Journal of International Money and Finance, 21(6):777-793.

Rousseau PL, Wachtel P (2011): What is Happening to the Impact of Financial Deepening on Economic Rrowth? Economic Inquiry, 49(1):276-288.

Schaeck K, Cihak M, Wolfe S (2009): Are Competitive Banking Systems More Stable? Journal of Money, Credit and Banking, 41(4):711-734.

Thakor AV (2012): Incentives to Innovate and Financial crises. Journal of Financial Economics, 103(1):130-148.

Unite AA, Sullivan MJ (2003): The Effect of Foreign Entry and Ownership Structure on the Philippine Domestic Banking Market. Journal of Banking \& Finance, 27(12):2323-2345. 